\title{
Verbal Projection of Comparable Translations of a Detective Story
}

\author{
Yan Wang \\ Lecturer, Department of Translation, Faculty of Arts, The Chinese University \\ of Hong Kong, Hong Kong, China \\ wangyan@cuhk.edu.hk
}

\begin{abstract}
Based on the systemic functional framework, this paper attempts to compare verbal projection in two comparable translated texts of a detective story entitled A Scandal in Bohemia, one from the early 2oth century (henceforth TT1) and the other from the early 21st century (henceforth TT2). Approximately one hundred years apart, these two translations are strikingly different in their language use, with classical Chinese being used in TT1 and plain (colloquial) Chinese being used in TT2. By analysing and comparing the lexicogrammatical features of the verbal clauses in the two translated texts, this paper summarises the choices made by the translators in these two different historical moments: when translating the source text, TT1 translators show more flexibility by incorporating more addition and omission into their translation than TT2 translators.
\end{abstract}

\section{Keywords}

comparable translations - verbal projection - translators' choices

\section{Introduction to Verbal Projection}

As detailed by Halliday and Matthiessen (2004; 2014) and Halliday and McDonald (2004), there are six process types in English and four in Chinese. However, not all these process types will be dealt with in this paper, only verbal types will be studied. As the study is centred around a detective story, which is narrated by using a large number of dramatised dialogues, it is worth 
investigating verbal clauses. Halliday and Matthiessen (2014:302) mention that "clauses of saying are an important resource in various kinds of discourse, and they contribute to the creation of narrative by making it possible to set up dialogic passages" and "when narrative passages are constructed in conversation, verbal clauses are often used to develop accounts of dialogue on the model of ' $x$ said, then $y$ said' together with quotes of what was said". This pattern is frequently identified in detective stories, and certainly serves as an important resource for exploring verbal clauses and comparing Chinese translations. This also explains why this paper focuses on verbal projection instead of mental projection, although the latter is also a resource of projection. Therefore, of the various aspects which are encompassed in detective stories, this paper focuses on one aspect in particular, namely verbal clauses.

Projection typically involves "a projecting clause and a projected clause, or a combination of projected clauses" (Matthiessen and Teruya, 2013: 51. In the case of quoted speech, "the projecting clause includes a verb of 'saying', the most common in English being say, and the projected passage is fairly unrestricted in terms of speech function" (Matthiessen and Teruya, 2013: 51). There are in fact three systems involved in the differentiation of different kinds of projection: (i) the level of projection (idea vs. locution), (ii) the mode of projection (hypotactic reporting vs. paratactic quoting), and (iii) the speech function (projected proposition vs. projected proposal) (Halliday and Matthiessen, 2014: 509)

Level of projection and mode of projection intersect to define four types of projection nexus: quoting direct speech, reporting indirect speech, reporting speech and quoting thought. As reporting indirect speech and reporting speech are projected by mental processes, quoting direct speech and quoting thought, which are projected by verbal processes, will be the main categories studied in this paper. Two examples are chosen from the text of $A$ Scandal in Bohemia to illustrate these two categories:

(1) When verbal clauses project indirect speech (hypotactic) I had been told that it would certainly be you.

(2) When verbal clauses project direct quotation (paratactic) "It is quite a pretty little problem," said he.

As stated in Halliday and McDonald (2004), in Chinese, the prototypical verb in verbal clauses is 'say', which is used in general contexts, e.g., Ni shuo shenme? You said what? Shuo projects quoted speech in all speech functions, and can 
TABLE 1 Meanings of the typical verbs of saying

\begin{tabular}{ll}
\hline Verbs of saying & Meaning \\
\hline reply & say in response \\
explain & say in explanation \\
protest & say with reservation \\
continue & go on saying \\
add & say in addition \\
interrupt & say out of turn \\
warn & say: undesirable consequences \\
insist & say emphatically \\
complain & say irritably \\
cry; shout & say loudly \\
boast & say proudly \\
murmur & say sotto voce \\
stammer & say with embarrassment \\
threaten & offer: undesirable \\
vow & offer: sacred \\
promise & offer: desirable \\
agree & offer: in response \\
blare; thunder & order imperiously \\
moan & plead whiningly \\
yell & order vociferously \\
fuss & order officiously \\
\hline
\end{tabular}

be added to verbs in other process types to enable them to project: Ta xiaozhe shuo, 'Ni bie lai shuo zhetao.' He said, laughing: 'Don't say that to me.'

There are different verbs of saying, some with additional circumstantial features, which may influence translations. The meanings of some typical verbs of saying are generalised below (adapted from Halliday and Matthiessen, 2014: 514).

For instance, when we know that reply means 'say in response', we are in a better position to explain why the Chinese translation can be '回答' (hui da; reply) or '回答说; 回答道' (hui da shuo; hui da dao), with the latter implying the meaning of 'response'.

Wierzbicka (1987) provides a comprehensive and most detailed analysis of the verbs of saying, which are categorised into 37 groups. For instance, the verb 'ask' is one of the most common verbs in English, but we need to differentiate 
between 'ask' in the sense of 'asking a question' and 'ask' in the sense of 'asking someone to do something' (Wierzbicka, 1987: 66). In terms of projection, the first meaning is often adopted to ask questions when projecting direct speech.

Matthiessen and Teruya (2013) undertake an important investigation of projection in terms of the quoting strategies used in English, but there are few other works on projection, particularly within the Chinese context. There are even fewer studies on verbal projection, but Zeng (2006), Liang and Zeng (2016), and Zeng and Liang (2019) contribute to the study of projection in both English and Chinese. Despite an abundance of translations of various works since the Late Qing period, studies on these translations are comparatively limited, with only a few sporadic papers and MA theses considering early translation in the Late Qing period. For instance, Zhang (2010) explores the translation of detective stories in the late Qing period from the perspective of polysystem theory; $\mathrm{Yu}$ (2004) discusses the significance of China's modern translation of detective stories; Zhang and Lin (2006) provide an assessment of the partial translations of The Complete Sherlock Holmes; Zhang (2002) focuses on the two translation upsurges of detective stories in China. However, few studies have been undertaken into either later translations or the comparative analysis of different translations. Therefore, this study attempts to fill this gap by comparing two translations of a detective story from different time periods.

\section{Research Methodology and Two Comparable Translations}

This section presents the methods adopted in the current research. This study falls within the broad scope of descriptive translation studies (DTS), a methodology developed by Toury (1995). DTs dates from the early 1970s when translation studies claimed itself to be a scientific and independent study by Holmes (1972/1988). The term descriptive is the opposite of prescriptive, signalling "the rejection of the idea that the study of translation should be geared primarily to formulating rules, norms or guidelines for the practice or evaluation of translation or to developing didactic instruments for translator training" (Hermans, 1999: 7). Besides, DTS moves translation studies from prescribing 'good' or 'correct' translation to describing and explaining actual translation behaviour, and it is only "through studies into actual behavior that hypotheses can be put to a real test" (Toury, 1995: 16-17). In other words, a descriptive study does not involve value judgment, and the current study does not intend to indicate whether one translation is better or worse than the other, but its aim is only to describe the linguistic features in both translations without subjective preference. Therefore, descriptive research is designed to 
obtain information concerning the current status of a phenomenon and its aim is to describe what exists at the time of the research (Ary, 1979: 295), which is more scientific and objective. As indicated by Toury, DTs "aspires to offer a framework for individual studies" (Toury, 1995: 11), and therefore is understood to be a model that sets guidelines for research on actual translation problems.

Because DTS focuses on "observable aspects of translation, it has also been called empirical" (Hermans, 1999: 7). Located within the framework of DTS, this is an empirical study, which conducts a descriptive investigation into the Chinese translations of a detective story. Since this study involves two translations from different time periods, a comparative study will be conducted. According to Toury, there are three types of comparison in translation studies: first, comparing parallel translations into one language, which came into being during different periods of time; second, comparing different phases of the emergence of a single translation; third, comparing translations into different languages (Toury, 1995: 73-74). The current study focuses on the first type of comparison.

With a view to investigating the features of verbal clauses in a detective story and comparing the differences between two Chinese translations - the 1917 translation, i.e. the early 2 oth century (literary language or classical Chinese) (henceforth TT1) and the 2011 translation, i.e., the early 21st century (plain language or colloquial Chinese) (henceforth тт2) - A Scandal in Bohemia written by Conan Doyle (henceforth ST) and its two Chinese translations are selected for analysis and comparison.

This short story, A Scandal in Bohemia, depicts Sherlock Holmes' solution to an assignment posed by the King of Bohemia. Holmes' assignment is to recover a photograph of the King with his lover, Irene Adler, who is threatening to disclose her relationship with the King by showing this photograph to the King's bride at their wedding. Translated by Changjue and Xiaodie, the title of TT1 is Pretty Figure (qiàn yǐng), which is markedly different from the original title. However, the translation into Bohemian scandal (bō xī mǐ yà chǒu wén) by Chen Yulun (тт2) is more faithful to the original title. In order to explore the differences and similarities between the two Chinese translations, this paper focuses on the lexicogrammatical features of these two translations.

To analyse and compare the two translations, тT1 and тт2, of $A$ Scandal in Bohemia, this paper adopts systemic functional theories. Informed by systemic functional linguistics (SFL), a language is a complex semiotic system with various levels or strata (Halliday and Matthiessen, 2014: 24). SFL consists of five strata - phonetics, phonology, lexicogrammar, semantics and context. Comparatively speaking, lexicogrammar serves as the basis for textual analysis, by reflecting various lexicogrammatical features. So, this paper focuses on 


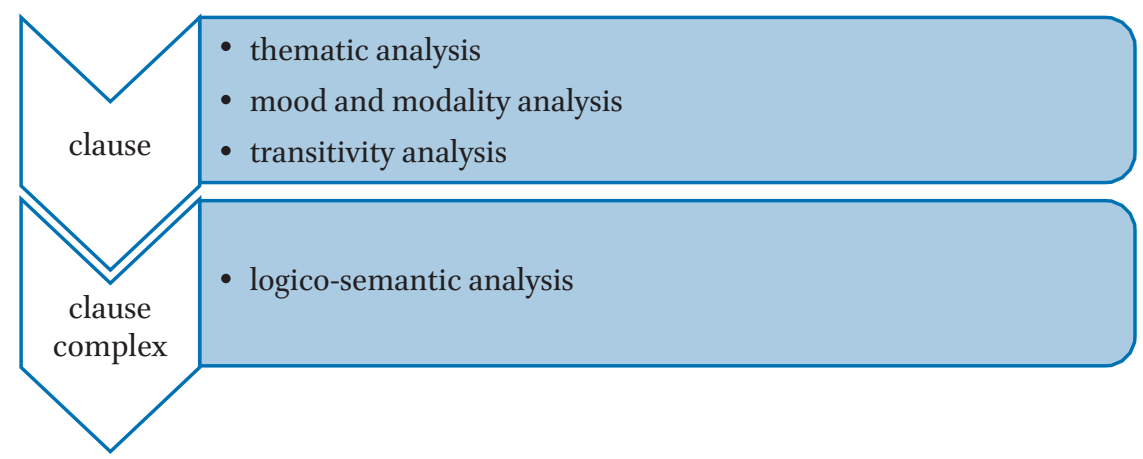

FIGURE 1 Theoretical framework: analysis at the lexicogrammatical stratum

the lexicogrammatical stratum for analysis and comparison. Another important concept of SFL is metafunction, of which there are four types, i.e., textual, interpersonal, experiential and logical metafunctions, which are intrinsic to language. In order to compare the similarities and differences of the two translations, this paper conducts an analysis of all four metafunctions. More specifically, it begins with a thematic analysis (textual metafunction), then a mood and modality analysis (interpersonal metafunction), then a transitivity analysis (experiential metafunction) and, finally, a logico-semantic analysis (logical metafunction).

All verbal clauses projecting direct or indirect speech were extracted from the text, which created a corpus of 70 verbal clauses projecting direct speech and 12 projecting indirect speech. ${ }^{1}$ In this section, analyses will be presented to compare the differences between тT1 and тт2.

\subsection{Thematic Analysis}

On the basis of the Thematic analysis of the ST, TT1 and TT2 and the comparisons between them, the following observations can be made:

(1) In terms of textual Theme, there is only one textual Theme in the sT and TT2, but 7 textual Themes in TT1 (see Table 2).

(2) In terms of interpersonal Theme, there are no interpersonal Themes in the parallel texts when the verbal clauses project direct speech.

(3) In terms of topical Theme, it can be seen from Table 3 that:

1 In this paper, only the 70 verbal clauses projecting direct speech will be analysed. 
TABLE 2 Distribution of textual Themes when projecting direct speech in the ST, TT1 and TT2

\begin{tabular}{|c|c|c|c|c|c|}
\hline ST & Freq. & TT1 & Freq. & TT2 & Freq. \\
\hline \multirow[t]{4}{*}{ when } & 1 & 乃 (PY: nǎi; BT: then)a & 3 & 并 (PY: bìng; BT: and) & 1 \\
\hline & & 但 (PY: dàn; BT: but) & 2 & & \\
\hline & & 则 (PY: zé; BT: then) & 1 & & \\
\hline & & 时 (PY: shí; BT: when) & 1 & & \\
\hline
\end{tabular}

a The Chinese characters in the example tables are accompanied by PY (Pin Yin), IG (Interlinear Glossing) and вт (Back Translation), following Halliday and McDonald's (2004) convention.

TABLE 3 Distribution of topical Themes when projecting direct speech in the ST, TT1 and TT2

\begin{tabular}{|c|c|c|c|c|c|}
\hline ST & Freq. & TT1 & Freq. & TT2 & Freq. \\
\hline $\begin{array}{l}\text { Process: } \\
\text { said: 25; } \\
\text { cried: 3; } \\
\text { murmured: 3; } \\
\text { asked: 2; } \\
\text { remarked: 2; } \\
\text { answered: 1; } \\
\text { continued: 1; } \\
\text { returned: 1; } \\
\text { shouted: } 1 \\
\text { Participant: } \\
\text { he: } 18 ; \\
\text { I: 9; } \\
\text { she: } 3 ; \\
\text { someone: } 1\end{array}$ & 39 & $\begin{array}{l}\text { Participant: } \\
\text { 福/ 福尔摩斯 } \\
\text { (PY: fú/fú ěr mó sī; } \\
\text { B T: Holmes): 19; } \\
\text { 予 (PY: yú; BT: I): 5; } \\
\text { 王 (PY: wáng; } \\
\text { B T: King): 4; } \\
\text { 客 (PY: kè; BT: } \\
\text { visitor): 2;一人 } \\
\text { (PY: yī rén; BT: } \\
\text { one person): 1; } \\
\text { 又一人 (PY: yòu yī } \\
\text { rén; B T: another } \\
\text { person): 1; 集 } \\
\text { (PY: jí; BT: all): 1 }\end{array}$ & 33 & $\begin{array}{l}\text { Participant: 福尔摩斯 } \\
\text { (PY: fú ěr mó sī; } \\
\text { BT: Holmes): 16; 他 } \\
\text { (PY: tā; BT: he): 18; } \\
\text { 我 (PY: wǒ; B T: I): 11; } \\
\text { 她 (PY: tā; BT: she): 3; } \\
\text { 国王/ 波西米亚国王 } \\
\text { (PY: guó wáng /bō xī mǐ } \\
\text { yà guó wáng; BT: King/ } \\
\text { King of Bohemia): 4; } \\
\text { 我们这位陌生的不速 } \\
\text { 之客 (PY: wǒ men zhè } \\
\text { wèi mò shēng de bú sù } \\
\text { zhī kè; BT: our strange } \\
\text { visitor): 1; 一个女人 } \\
\text { (PY: yī gè nŭ rén; BT: } \\
\text { one woman): 1; 另一声音 } \\
\text { (PY: lìng yī shēng yīn; } \\
\text { BT: another voice): 1; } \\
\text { 几个声音 (PY: jǐ gè shēng } \\
\text { yīn; BT: several voices): 1 }\end{array}$ & $5^{6}$ \\
\hline
\end{tabular}


- Some elliptical topical Themes are identified in the three texts.

- The topical Theme of 'he' appears 18 times in both the sт and тт2, but not in TT1.

- The marked theme in the ST is prominent; 39 of the topical Themes are Process (verbs of saying) which serve as the topical Theme, and these are clearly marked in the English system. However, because of Chinese linguistic features, in the Chinese texts, verbs of saying cannot shoulder the role of theme, not even a marked theme.

- In TT1 and тT2, there are a number of topical Themes of 'Sherlock Holmes', 'Holmes' or 'the King', and this differs from the sT. We find that the Chinese translations tend to give more explicit information to the reader about who has said or asked something, but another reason for this is that the verbs of saying cannot be thematised in the same way as in the English text.

- All the topical Themes in TT1 and TT2 are unmarked, while in the ST more than half are marked in the English system with verbs of saying.

- One point which requires further exploration are the circumstances under which verbs of saying are used as marked themes and whether they are consistently used in this way. This can help to determine whether such verbs of saying in narrative texts should be considered as being marked or unmarked.

\subsection{Mood and Modality Analysis}

Based on the Mood and Modality analysis of the ST, TT1 and TT2 and the comparisons between them, the following observations can be made:

(1) In terms of FREEDOM (whether the clause is free or bound), all the clauses are free in the ST, except clause 59 which is bound, and all the clauses are free in TT1 and TT2.

(2) In terms of MOOD TYPE, ${ }^{2}$ all the clauses are indicative: declarative in this corpus.

(3) In terms of POLARITY (whether the clause is positive or negative), all the clauses are positive in this corpus.

(4) In terms of DEICTicity (whether the clause is temporal or modal), all the clauses are temporal in this corpus.

(5) As seen in Table 4, the Subject in the ST differs from the Theme in the ST, while in unmarked declarative clauses, the Subject conflates with

2 There are four main mood types: imperative, declarative, wH-interrogative and yes/no interrogative. 
TABLE 4 Distribution of Subjects when projecting direct speech in the ST, TT1 and TT2

\begin{tabular}{|c|c|c|c|c|c|}
\hline ST & Freq. & TT1 & Freq. & TT2 & Freq. \\
\hline Holmes & 17 & $\begin{array}{l}\text { 福/ 福尔摩斯 } \\
\text { (PY: fú/fú ěr mó sī; } \\
\text { BT: Holmes) }\end{array}$ & 19 & $\begin{array}{l}\text { 福尔摩斯 (PY: fú ěr } \\
\text { mó sī; BT: Holmes) }\end{array}$ & 16 \\
\hline he & 26 & & & 他 (PY: tā; вт: he) & 18 \\
\hline I & 12 & 予 (PY: yú; BT: I) & 5 & 我 (PY: wǒ; BT: I) & 11 \\
\hline she & 4 & & & 她 (PY: tā; вT: she) & 3 \\
\hline $\begin{array}{l}\text { the King/the } \\
\text { King of } \\
\text { Bohemia }\end{array}$ & 4 & $\begin{array}{l}\text { 王 (PY: wáng; } \\
\text { BT: King) }\end{array}$ & 4 & $\begin{array}{l}\text { 国王/ 波西米亚国王 } \\
\text { (PY: guó wáng /bō xī } \\
\text { mǐ yà guó wáng; BT: } \\
\text { King/King of Bohemia) }\end{array}$ & 4 \\
\hline $\begin{array}{l}\text { our strange } \\
\text { visitor }\end{array}$ & 2 & $\begin{array}{l}\text { 客 (PY: kè; } \\
\text { BT: visitor) }\end{array}$ & 2 & $\begin{array}{l}\text { 我们这位陌生的不速 } \\
\text { 之客 (PY: wǒ men zhè } \\
\text { wèi mò shēng de bú sù } \\
\text { zhī kè; BT: our strange } \\
\text { visitor) }\end{array}$ & 1 \\
\hline a woman & 1 & & & $\begin{array}{l}\text { 一个女人 (PY: yī gè nü } \\
\text { rén; BT: one woman) }\end{array}$ & 1 \\
\hline someone & 1 & $\begin{array}{l}\text { 一人 (PY: yī rén; } \\
\text { BT: one person) }\end{array}$ & 1 & & \\
\hline another & 1 & $\begin{array}{l}\text { 又一人 (PY: yòu } \\
\text { yī rén; в T: } \\
\text { another person) }\end{array}$ & 1 & $\begin{array}{l}\text { 另一声音 (PY: lìng yī } \\
\text { shēng yīn; BT: another } \\
\text { voice) }\end{array}$ & 1 \\
\hline $\begin{array}{l}\text { several } \\
\text { voices }\end{array}$ & 1 & 集 (PY:jí; BT: all) & 1 & $\begin{array}{l}\text { 几个声音 (PY: jǐ gè shēng } \\
\text { yīn; BT: several voices) }\end{array}$ & 1 \\
\hline my companion & 1 & & & & \\
\hline
\end{tabular}

the Theme; but as the sт has quite a number of marked declarative clauses with verbs of saying, this differs in terms of the Subject and topical Theme. However, the distribution of the Theme and Subject remains the same in the two Chinese translations, as the verbal clauses in Chinese are unmarked declarative clauses.

(6) In terms of Finite verbs, as shown in Table 5, the most frequently used verb of saying is 'said'. This is a similar feature of the translations, with the translations using ‘曰' (PY: yuē; BT: say) in TT1 and '说' (PY: shuō; BT: say) in TT2. 
TABLE 5 Distribution of Finite verbs when projecting direct speech in the ST, TT1 and TT2

\begin{tabular}{|c|c|c|c|c|c|}
\hline ST & Freq. & TT1 & Freq. & TT2 & Freq. \\
\hline said & 31 & $\begin{array}{l}\text { 曰/ 言曰 (PY: yuē/ } \\
\text { yán yuē; BT: say) }\end{array}$ & 33 & $\begin{array}{l}\text { 说 (道)/ 说着 (PY: shuō } \\
\text { (dào)/shuō zhe; BT: say) }\end{array}$ & 36 \\
\hline answered & 5 & $\begin{array}{l}\text { 应曰 (PY: yīng yuē; } \\
\text { BT: answer) }\end{array}$ & 1 & $\begin{array}{l}\text { (回) 答道/ 回答说 } \\
\text { (PY: (huí)dá dào /huí } \\
\text { dá shuō; BT: answer) }\end{array}$ & 9 \\
\hline asked & 8 & & & $\begin{array}{l}\text { 问道 (PY: wèn dào; } \\
\text { BT: ask) }\end{array}$ & 8 \\
\hline shouted & 9 & $\begin{array}{l}\text { 争呼曰/ 呼曰 } \\
\text { (PY: zhēng hū } \\
\text { yuē /hū yuē; } \\
\text { BT: shout) }\end{array}$ & 3 & $\begin{array}{l}\text { 高叫着 (PY: gāo jiào } \\
\text { zhe; BT: shout) }\end{array}$ & 1 \\
\hline cried & 2 & & & $\begin{array}{l}\text { 喊道 (PY: hăn dào; } \\
\text { BT: cry) }\end{array}$ & 9 \\
\hline murmured & 3 & $\begin{array}{l}\text { 渌言曰 (PY: chán } \\
\text { yán yuē; BT: } \\
\text { murmur) }\end{array}$ & 1 & $\begin{array}{l}\text { 喃喃地说 (道) } \\
\text { (PY: nán nán dì } \\
\text { shuō (dào); } \\
\text { BT: murmur) }\end{array}$ & 3 \\
\hline continued & 2 & $\begin{array}{l}\text { 接语曰 (PY: jiē } \\
\text { yǔ yuē; BT: } \\
\text { continue to say) }\end{array}$ & 1 & $\begin{array}{l}\text { 接着说 (PY: jiē zhe } \\
\text { shuō; BT: continue } \\
\text { to say) }\end{array}$ & 1 \\
\hline added & 1 & $\begin{array}{l}\text { 又曰 (PY: yòu yuē; } \\
\text { BT: say again) }\end{array}$ & 4 & $\begin{array}{l}\text { 继续说 (PY: jì xù shuō; } \\
\text { BT: add) }\end{array}$ & 1 \\
\hline returned & 1 & & & $\begin{array}{l}\text { 顶了 (PY: dǐng le; B T: } \\
\text { return) }\end{array}$ & 1 \\
\hline \multirow[t]{3}{*}{ remarked } & 8 & & & & \\
\hline & & 告 (PY: gào; BT: tell) & 1 & & \\
\hline & & $\begin{array}{l}\text { 低语曰 (PY: dī yǔ } \\
\text { yuē; B T: whisper) }\end{array}$ & 1 & & \\
\hline
\end{tabular}

\subsection{Transitivity Analysis}

On the basis of the Transitivity analysis of the ST, тT1 and TT2 and the comparisons between them, the following observations can be made:

(1) The Sayer is the same as the Subject in this corpus.

(2) Since this study's corpus is comprised of verbal clauses, the Process type is verbal, as indicated by the various verbs of saying, which are same as the Finite verbs in this corpus. 
(3) Six circumstantial elements are found in the verbal clauses of the st, but in the translations these elements have been changed, with some being ignored in the translation process, while others are changed to a separate clause.

\subsection{Logico-Semantic Analysis}

This section investigates projection in clause complexing (at the clause complex level), that is, the logico-semantic relations between the projecting clauses and the projected clauses in the two Chinese translations.

Based on the system of clause complexing, the systems of TAxIs and LOGICO-SEMANTIC RELATION intersect to define a basic set of clause nexuses.

(i) TAXIS (degree of interdependency): hypotaxis/parataxis. All clauses linked by a logico-semantic relation are interdependent: that is the meaning of relational structure - one unit is interdependent on another unit. Two clauses related as interdependent in a complex may be treated as being of equal status, or as being of unequal status. Degree of interdependency is known technically as taxis; and the two different degrees of interdependency as parataxis (equal status) and hypotaxis (unequal status). Hypotaxis is the relation between a dependent element and its dominant, the element on which it is dependent. Contrasting with this is parataxis, which is the relation between two like elements of equal status, one initiating and the other continuing. The distinction between parataxis and hypotaxis has evolved as a powerful grammatical strategy for guiding the rhetorical development of text, making it possible for the grammar to assign different statuses to figures within a sequence. The choice between parataxis and hypotaxis characterises each relation between two clauses (each nexus) within a clause complex; and clause complexes are often formed out of a mixture of parataxis and hypotaxis. (Halliday and Matthiessen, 2014: 440-441)

(ii) LOGICO-SEMANTIC RELATION: expansion/projection. There is a wide range of different logico-semantic relations any of which may hold between a primary and a secondary member of a clause nexus. But it is possible to group these into a small number of general types, based on the two fundamental relationships of (1) expansion: ${ }^{3}$ the secondary clause expands the primary clause, by (a) elaborating it, (b) extending it or (c) enhancing it; and (2) projection: the secondary clause is projected

3 Notation markers: elaborating =; extending + ; enhancing $\times$; locution “; idea ‘. The symbol ‘` means 'is followed by'. 
through the primary clause, which instates it as (a) a locution or (b) an idea. (Halliday and Matthiessen, 2014: 443)

Within the general categories of expansion and projection, we first recognise a small number of subtypes, as shown in Table 6.

Since this paper focuses on verbal projection, we only consider the representation of the content of saying (locutions) rather than the content of thinking (ideas). With respect to the mode of projection, on the basis of the 70 verbal clauses projecting direct speech and the 12 projecting indirect speech that were

TABLE 6 Types of logico-semantic relations

\begin{tabular}{|c|c|c|c|}
\hline Types & Subtypes & Notation & Definition \\
\hline \multirow[t]{3}{*}{ expansion } & elaborating & $\begin{array}{l}= \\
\text { (equals) }\end{array}$ & $\begin{array}{l}\text { One clause expands another by } \\
\text { elaborating on it (or some portion } \\
\text { of it): restating in other words, } \\
\text { specifying in greater detail, com- } \\
\text { menting or exemplifying (i.e., for } \\
\text { example, viz.) }\end{array}$ \\
\hline & extending & $\begin{array}{l}+ \\
\text { (is added to) }\end{array}$ & $\begin{array}{l}\text { One clause expands another by } \\
\text { extending beyond it: adding some } \\
\text { new element, giving an exception } \\
\text { to it or offering an alternative } \\
\text { (and, or) }\end{array}$ \\
\hline & enhancing & $\begin{array}{l}\times \\
\text { (is multiplied by) }\end{array}$ & $\begin{array}{l}\text { One clause expands another by } \\
\text { embellishing around it: qualifying } \\
\text { it with some circumstantial feature } \\
\text { of time, place, cause or condition } \\
\text { (so, yet, then) }\end{array}$ \\
\hline \multirow[t]{2}{*}{ projection } & locution & $\begin{array}{l}\text { “ double quotation } \\
\text { marks) }\end{array}$ & $\begin{array}{l}\text { One clause is projected through } \\
\text { another, which presents it as a } \\
\text { locution, a construction of } \\
\text { wording (says) }\end{array}$ \\
\hline & idea & $\begin{array}{l}\text { ( single quotation } \\
\text { marks) }\end{array}$ & $\begin{array}{l}\text { One clause is projected through } \\
\text { another, which presents it as an } \\
\text { idea, a construction of meaning } \\
\text { (thinks) }\end{array}$ \\
\hline
\end{tabular}

SOURCE: ADAPTED FROM HALLIDAY AND MATTHIESSEN (2014: 444) 
identified in this text, it is safe to say that we have 70 examples of parataxis and 12 examples of hypotaxis. By analysing the logico-semantic relations of verbal projection, we are able to identify the dominant logico-semantic patterns (e.g., hypotactic enhancement, paratactic extension or hypotactic projection/idea). Of the 82 verbal clause complexes, the distribution of hypotaxis and parataxis is shown in Table 7:

TABLE 7 Comparison of taxis in the ST, TT1 and TT2

\begin{tabular}{lccc}
\hline Taxis & ST & TT1 & TT2 \\
\hline hypotaxis & 12 & 5 & 10 \\
parataxis & 70 & 43 & 69 \\
\hline
\end{tabular}

From Table 7, we find that in the ST, тT1 and Tт2, parataxis occurs more frequently than hypotaxis, and the occurrence of parataxis and hypotaxis in TT1 is less than in the ST and тT2.

As an example, let us now consider one clause complex consisting of two clauses and one clause complex of three clauses. The distribution of the logicosemantic types is shown in Table 8:

TABLE 8 Comparison of the logico-semantic types in the ST, TT1 and TT2

\begin{tabular}{llll}
$\begin{array}{l}\text { Clauses in one } \\
\text { clause complex }\end{array}$ & ST & TT1 & TT2 \\
\hline 2 clauses & $" 1 \wedge 2(39$ times $)$ & $1^{\wedge}$ " $2(27$ times $)$ & $" 1 \wedge 2(34$ times $)$ \\
3 clauses & $"{ }^{\wedge}{ }_{2 \alpha} \wedge 2 \times \beta(12$ & $1 \wedge+2 \wedge$ " $3(3$ times $) ;$ & $" 1 \wedge 21 \wedge 2+2$ \\
& times $)$ & $1 \wedge$ " $2 \times \beta \wedge$ " $2 \alpha(2$ times $)$ & $(9$ times $)$ \\
\hline
\end{tabular}

The following two examples demonstrate the differences between TT1 and TT2:

Example 1:

ST

$\begin{array}{ll}\text { "Come in!" } & \text { "1 } \\ \text { said Holmes. } & 2\end{array}$




\begin{tabular}{|c|c|c|c|}
\hline TT1 & 福爾摩斯 & 乃 & 曰, \\
\hline PY: & fú ěr mó sī & năi & yuē \\
\hline IG: & Holmes & then & say \\
\hline BT: & Holmes & then & said \\
\hline & 进 & 也. & ${ }^{\prime 2}$ \\
\hline PY: & jìn & yě & \\
\hline IG: & enter & MOD: imp & \\
\hline BT: & Come in & & \\
\hline TT2 & “请 & 进 & 来!” \\
\hline PY: & qǐng & jìn & lái \\
\hline IG: & Please & enter & PV: come \\
\hline BT: & Please & come in & \\
\hline & 福尔摩斯 & 说. & 2 \\
\hline PY: & fú ěr mó sī & shuō & \\
\hline IG: & Holmes & say & \\
\hline BT: & Holmes & said & \\
\hline
\end{tabular}

From this example, we find that TT2 follows the st closely, sharing the same logico-semantic pattern of projected clause ${ }^{\wedge}$ projecting clause. However, TT1 differs in terms of the sequence of the projecting clause and projected clause, and the reason for this is that, in classical Chinese, the sequence of the projected clause and projecting clause cannot be reversed. Therefore, its logico-semantic patterns differ from those seen in the ST and тт 2 .

Example 2:

ST "The man [[who wrote it]] was presumably well to do," "1 I remarked, $\quad 2 \alpha$ endeavouring to imitate my companion's processes. $\quad 2 \times \beta$

\begin{tabular}{lllllllll} 
TT1: & 乃 & 力 & 仿 & 其 & 觀察 & 之 & 狀態, $[\ldots]$ & 1 \\
PY: & năi & lì & făng & q1́ & guān chá & zhī & zhuàng tài & \\
IG: & PCON & hard & imitate & his & observe & SUB & state \\
BT: & so & \multicolumn{1}{l}{ try to imitate his observing state, } & &
\end{tabular}




\begin{tabular}{|c|c|c|c|c|c|c|c|}
\hline 予 & 曰, & \multicolumn{2}{|c|}{+21} & & & & \\
\hline PY: & yuē & & & & & & \\
\hline IG: & say & & & & & & \\
\hline BT: & said & & & & & & \\
\hline 吾 & 知 & 此 & 人 & 富 & 而 & 無禮 & $+2 " 2$ \\
\hline wú & zhī & cǐ & rén & fù & ér & wú lǐ & \\
\hline I & know & DET & person & rich & but & impolite & \\
\hline I & know & this $\mathrm{F}$ & rson is ri & but $r$ & & & \\
\hline
\end{tabular}

TT2: “写这张 条子 的人 大概 相当 有钱” “1 PY: xiě zhè zhāng tiáo zǐ de rén dà gài xiàng yǒu IG: write this MEAS note SUB person probably pretty rich BT: "the person who wrote this note is probably pretty rich,"

$\begin{array}{llll} & \text { 我 } & \text { 说 } & \text { 着, } \\ \text { PY: } & \text { wǒ } & \text { shuō } & \text { zhe } \\ \text { IG: } & \text { I } & \text { say } & \text { ASP:impf } \\ \text { BT: } & \text { I } & \text { said } & \end{array}$

$\begin{array}{llllllll} & \text { 尽力 } & \text { 模仿 } & \text { 我 } & \text { 伙伴 } & \text { 的 } & \text { 推理 } & \text { 方法. } \\ \text { PY: jìn lì } & \text { mó fǎng } & \text { wǒ } & \text { huǒ bàn } & \text { de } & \text { tuī lǐ } & \text { fāng fǎ } \\ \text { IG: try } & \text { imitate } & \text { me } & \text { companion } & \text { su B } & \text { reason } & \text { method } \\ \text { BT: } & \text { trying to } & \text { imitate } & \text { my } & \text { companion's } & & \text { reasoning } & \text { method }\end{array}$

This example shows the pattern in the $\mathrm{sT}$ : projected clause $\wedge$ projecting clause $^{\wedge}$ hypotactic dependent clause that qualifies the projecting clause. TT2 also follows the ST closely, while TT1 differs in that the circumstantial element is changed to a separate clause, which is understood as extension rather than enhancement.

In this section, various analyses at both clause and clause complex levels have been conducted, revealing three findings. Firstly, from the analysis of textual Theme, interpersonal Theme and topical Theme, differences and similarities in the thematic choices are examined in the two Chinese translations. The position of the verbs of saying in the verbal clauses demonstrates linguistic differences between English and Chinese. Verbs of saying (Process) can 
serve as the topical Theme in English (highly marked), but is impossible in Chinese, which leads to different thematic choices. Secondly, from the analysis of mood and modality, we find the most frequently used subjects in the text are 'he', 'Holmes' and 'I', which shows that the main character in the text is Holmes, and ' $\mathrm{I}$ ' is used frequently in dialogues. Thirdly, three frequently used logico-semantic relations are identified in the source text: paratactic quoting, hypotactic enhancement and paratactic extension, and the preferred logicosemantic patterns are generalised as follows: (i) " $1 \wedge 2$; and (ii) " $1 \wedge 2 \alpha \wedge 2 \times \beta$. Also some logico-semantic relations are changed in the translation, particularly in TT1. For instance, " $1 \wedge 2$ in the ST is changed to $1 \wedge$ " 2 in TT1, while тT2 keeps the same sequence. Enhancement in the ST is sometimes changed to extension in TT1, in which a certain circumstantial element is changed to a separate clause.

In this section, we attempt to compare the choices made by the translators of TT1 and TT2 with the source text. Different choices are made by the translators, as seen in the two Chinese translations, and these differences will be illustrated by examples.

(1) Addition: This can be addition of projected clauses or projecting clauses. In this paper, addition refers to either the addition of comments by the translator in the projected clause, the addition of explanations of reasoning in the projected clause, or the addition of a connecting link in the projecting clause. For instance:

Example 3 shows the addition of comments in the projected clause.

Example 3

ST "Wedlock suits you," “1

he remarked. 2

\begin{tabular}{lllllllll} 
TT1 & 时 & 福 & 己 & 顾 & 予 & 笑 & 曰, & 1 \\
PY: & shí & fú & y̌ & gù & yú & xiào & yuē & \\
IG: & Then & Holmes & already & DISP & I & smile & say & \\
BT: & Then & Holmes & \multicolumn{2}{l}{ said to me with a smile } & &
\end{tabular}




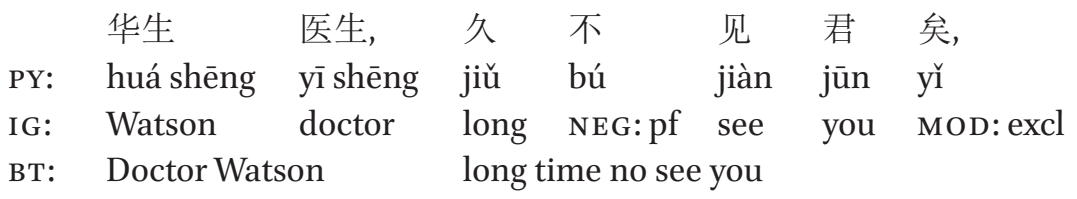

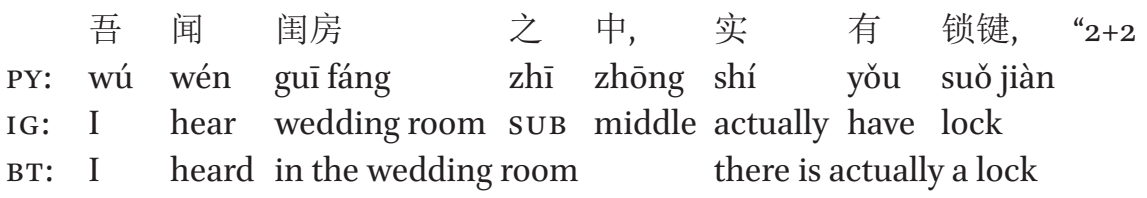

$\begin{array}{llllll} & \text { 人 } & \text { 而 } & \text { 得 } & \text { 妻, } & \text { “ } 2+3 \alpha \\ \text { PY: } & \text { rén } & \text { ér } & \text { dé } & \text { qī } & \\ \text { IG: } & \text { person but } & \text { get } & \text { wife } & \\ \text { BT: } & \text { a person gets a wife } & & & \end{array}$

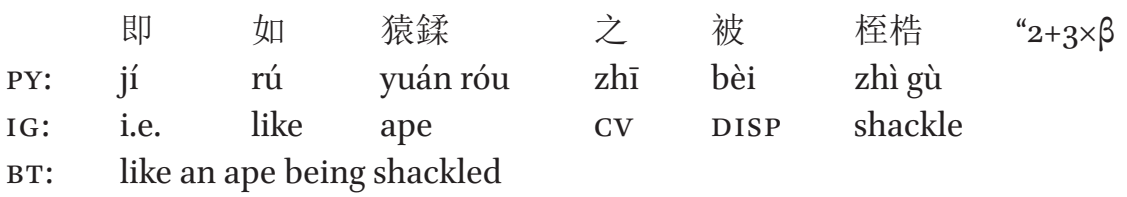

$\begin{array}{llllll} & \text { 君 } & \text { 其 } & \text { 一 } & \text { 也. } & \text { “2+4 } \\ \text { PY: } & \text { jūn } & \text { qí } & \text { ȳi } & \text { yě } & \\ \text { IG: } & \text { you } & \text { them } & \text { one } & \text { MOD:imp } & \\ \text { BT: } & \text { you are one of them. } & & & \end{array}$

\begin{tabular}{|c|c|c|c|c|c|}
\hline TT2 & “结婚 & 对 & 你 & 很 & 合适,” \\
\hline PY: & jié hūn & duì & nǐ & hěn & hé shì \\
\hline IG: & marriage & DISP & you & very & suit \\
\hline BT: & "marriage & is very & uitabl & ryou" & \\
\hline
\end{tabular}

$\begin{array}{lll} & \text { 他 } & \text { 说, } \\ \text { PY: } & \text { tā } & \text { shuō } \\ \text { IG: } & \text { he } & \text { say } \\ \text { BT: } & \text { he } & \text { said }\end{array}$

TT2 closely follows the ST, and the logico-semantic relations stay the same as in the ST. However, TT1 adds a great deal of information that does not exist in the ST. This added information are the comments or opinions of the translator. In this example, the clause ‘时福已顾予笑曰’ (в т: Then Holmes said to 
me with a smile) is not considered to be addition, because we can find the corresponding information in the ST in the previous context: 'Then he stood before the fire and looked me over in his singular introspective fashion.' Since certain information is added in the translation, logico-semantic relations are used to expand the translation, and it can be seen that the translator actively uses logico-semantic relations to link this newly-added information. In this example, the logico-semantic relations of paratactic extension and hypotactic enhancement are used to link the clauses '華生醫生, 久不見君矣, 吾聞閏房 之中, 實有鎖鍵, 人而得妻, 即如猿猱之被桎梏, 君其一也' (в long time no see you, I heard in the wedding room, there is actually a lock, a person gets a wife, like an ape being shackled, and you are one of them), and these clauses are new material added by the translator.

Example 4 shows the addition of repetitive information or the emphasising of information mentioned in the projected clause.

Example 4

ST

$\begin{array}{ll}\text { "Seven!" } & \text { "1 } \\ \text { I answered. } & 2\end{array}$

$\begin{array}{lllll}\text { TT1: } & \text { 予 } & \text { 笑 } & \text { 應 } & \text { 曰, } \\ \text { PY: } & \text { yú } & \text { xiào } & \text { yīng } & \text { yuē } \\ \text { IG: } & \text { I } & \text { smile } & \text { answer } & \text { say } \\ \text { BT: } & \text { I } & \text { answer with a smile } & \end{array}$

$\begin{array}{llllll} & \text { 增 } & \text { 七 } & \text { 磅 } & \text { 耳, } & \text { “21 } \\ \text { PY: } & \text { zēng qi } & \text { bàng } & \text { ěr } & \\ \text { IG: } & \text { add seven pound } & \text { MOD: imp } & \\ \text { BT: } & \text { I put on seven pounds } & & \end{array}$

$\begin{array}{lllll} & \text { 半 則 } & \text { 未 } & \text { 也. } & \text { “2=2 } \\ \text { PY: } & \text { bàn zé } & \text { wèi } & \text { yě } & \\ \text { IG: } & \text { half PCON NEG } & \text { MOD:imp } & \\ \text { BT: } & \text { but half is not yet } & & \end{array}$

$\begin{array}{lll}\text { TT2: } & \text { “七 } & \text { 磅.” “1 } \\ \text { PY: } & \text { qi } & \text { bàng } \\ \text { IG: } & \text { seven } & \text { pound } \\ \text { BT: } & \text { seven } & \text { pounds }\end{array}$




\begin{tabular}{|c|c|c|c|}
\hline & 我 & 回答 & 说. \\
\hline PY: & wǒ & huí dá & shuō \\
\hline IG: & I & answer & say \\
\hline BT: & I & answered & \\
\hline
\end{tabular}

In the projected clause, '半則未也' (вт: but half is not yet) is added to emphasise Watson's response that he actually put on seven pounds rather than seven and a half pounds.

Example 5 shows the addition of explanations of logical reasoning in the projected clause.

Example 5

ST

"It is simplicity itself,"

"11

[from text 1$]$

$<<$ said he; $>>$

2

"my eyes tell me

$" 1=2 \alpha$

that on the inside of your left shoe, [[just where

$" 1=2 " \beta$

the firelight strikes it,]] the leather is scored by

six almost parallel cuts."

\begin{tabular}{|c|c|c|c|c|c|}
\hline TT1: & 福 & 乃 & 莞爾 & 笑 & 曰, \\
\hline PY: & fú & nǎi & wǎn ěr & xiào & yuē \\
\hline IG: & Holmes & then & smile & smile & say \\
\hline BT: & Holmes & then & said wit & smile & \\
\hline
\end{tabular}

$\begin{array}{llll} & \text { 孺子 } & \text { 聽 } & \text { 之. } \\ \text { PY: } & \text { rúzì } & \text { tīng } & \text { zhī } \\ \text { IG: } & \text { you } & \text { listen } & \text { this } \\ \text { BT: } & \text { you } & \text { listen } & \text { this }\end{array}$

$\begin{array}{llllllll} & \text { 上帝 } & \text { 既 } & \text { 付 } & \text { 吾人 } & \text { 以 } & \text { 目, } & \text { “ } 2+2 \times \beta \\ \text { PY: } & \text { shàng dì } & \text { jì } & \text { fù } & \text { wú rén } & \text { y̌̌ } & \text { mù } & \\ \text { IG: } & \text { God } & \text { PCON } & \text { give } & \text { we person } & \text { PCON } & \text { eye } & \\ \text { BT: } & \text { The God } & \text { gives us eyes } & & & \end{array}$

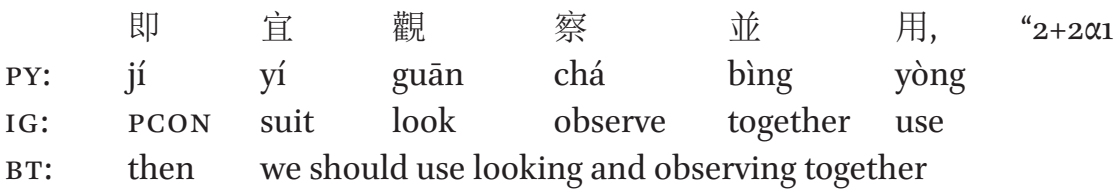


但能觀而不能察者, 實 違

PY: dàn néng guān ér búnéng chá zhě shí wéi

IG: but AUX look but cannot observe NOM actually breach 帝旨. “ $2+2 \alpha \times 2$

dì zhì

God will

Bт: but being able to look rather than observe is actually breaching God's will

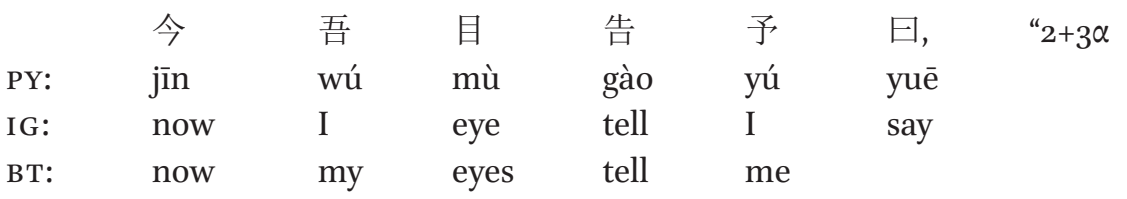

華生左靴之上沾有宿泥, “ $2+3$ “ $\beta_{1}$

PY: huá shēng zuǒ xuē zhī shàng zhān yǒu xiǔ ní

IG: Watson left shoe suB above cover exist old mud

в т: Watson's left shoe is covered with yesterday's mud

\begin{tabular}{|c|c|c|c|c|c|c|c|c|}
\hline & 今 & 已 & 化 & 為 & 平行 & 之 & 線, & $" 2+3 " \beta \times 21$ \\
\hline PY: & jīn & yǐ & huà & wéi & píng xíng & zhī & xiàn & \\
\hline IG: & now & already & turn & PV: become & parallel & SUB & line & \\
\hline
\end{tabular}

$\begin{array}{llllll} & \text { 數 } & \text { 凡 } & \text { 六 } & \text { 七 } & \text { “2+3“ } \beta \times 2=2 \\ \text { PY: } & \text { shù } & \text { fán } & \text { liù } & \text { qī } & \\ \text { IG: } & \text { count } & \text { all } & \text { six } & \text { seven } & \\ \text { BT: } & \text { counting as six or seven } & & \end{array}$

\begin{tabular}{llllll} 
TT2 & “这些 & 事 & 本身 & 很 & \multicolumn{1}{c}{ 简单,” } \\
PY: & zhè xiē & shì & běn shēn hěn & jiăn dān & hěn \\
IG: & these & thing & itself & very & simple \\
BT: & these & things & are very simple themselves \\
& & & \\
& $<<$ 他 & 说, >> & 2 & \\
PY: & tā & shuō & & \\
IG: & he & say & & \\
BT: & he & said &
\end{tabular}




$\begin{array}{lllllll} & \text { “我 } & \text { 的 } & \text { 眼睛 } & \text { 告诉 } & \text { 我, } & \text { “1=2 } \alpha \\ \text { PY: } & \text { wǒ } & \text { de } & \text { yăn jīng } & \text { gào sù } & \text { wǒ } & \\ \text { IG: } & \text { I } & \text { SUB } & \text { eye } & \text { tell } & \text { I } \\ \text { BT: } & \text { my } & & \text { eyes } & \text { tell } & \text { me }\end{array}$

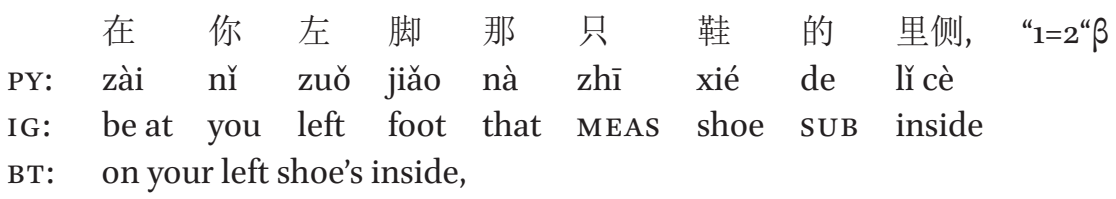

\begin{tabular}{|c|c|c|c|c|c|c|}
\hline [[也 & 就是 & 炉火 & 刚好 & 照到 & 的 & 地方]], \\
\hline yě & jiùshì & lú huǒ & gang hǎo & zhàodào & de & dìfāng \\
\hline VADV & PCON be & firelight & happen & shine & SUB & place \\
\hline
\end{tabular}

вт: that is, the place where the firelight happened to shine

其面上有六道年平行 的裂痕。” PY: qí miàn shàng yǒu liù dào jǐhū píng xíng de liè hén IG: it above exist six MEAS almost parallel SUB cut вт: its surface has six almost parallel cuts.

In this example, TT1 adds information that does not exist in the ST: '上帝既 付吾人以目, 即宜观察并用, 但能观而不能察者, 实违帝旨' (вт: The God gives us eyes, then we should use looking and observing together, but being able to looking rather than observing, is actually breaching God's will). This information is concerned with how God has guided Holmes' eyes to observe the inside of Watson's left shoe, and this information is used to demonstrate Holmes' logical reasoning process.

(2) Omission: This can be the omission of the projected clause, the projecting clause or both.

Example 6 shows the omission of both the projecting clause and the projected clause.

Example 6

ST: You did not tell me that you intended to go into harness.

TT1: Omission of both the projecting clause and the projected clause 


$\begin{array}{llllllll}\text { TT2 } & \text { 可是 } & \text { 你 } & \text { 过去 } & \text { 没 } & \text { 告诉 } & \text { 过 } & \text { 我, } \\ \text { PY: } & \text { kě shì } & \text { nǐ } & \text { guò qù } & \text { méi } & \text { gào sù } & \text { guò } & \text { wǒ } \\ \text { IG: } & \text { but } & \text { you } & \text { past } & \text { NEG:pf } & \text { tell } & \text { ASP } & \text { me } \\ \text { BT: } & \text { But you previously did not tell me, } & & & \end{array}$

$\begin{array}{llll} & \text { 你 } & \text { 打算 } & \text { 行医. } \\ \text { PY: } & \text { nı̌ } & \text { dǎ suàn } & \text { xíng yī } \\ \text { IG: } & \text { you } & \text { plan } & \text { practice } \\ \text { BT: } & \text { you plan to practice medicine. }\end{array}$

Example 7 shows the omission of the projected clause.

Example 7

ST: "Quite so," he answered, lighting a cigarette, and throwing himself down into an armchair.

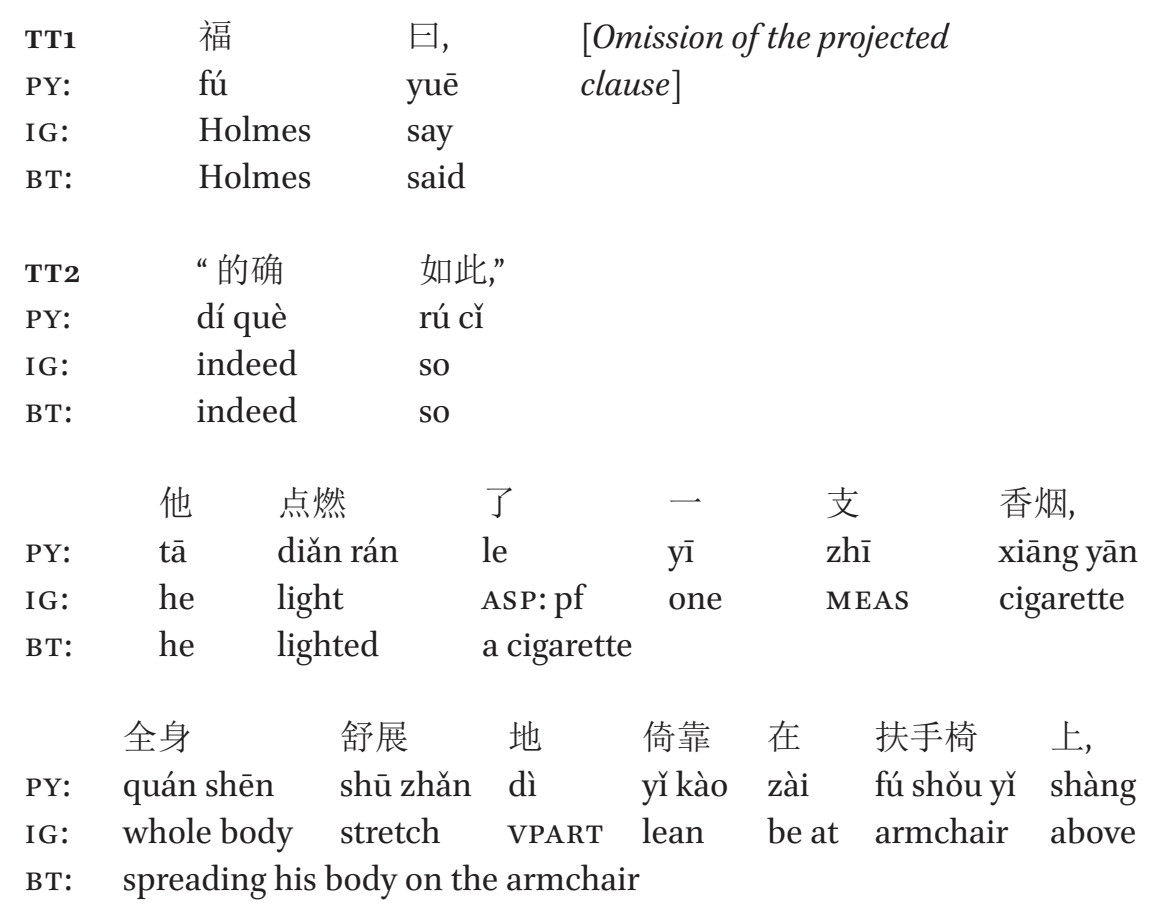




$\begin{array}{lll} & \text { 回答 } & \text { 道, } \\ \text { PY: } & \text { huí dá } & \text { dào } \\ \text { IG: } & \text { answer } & \text { PV: talk } \\ \text { BT: } & \text { answered } & \end{array}$

TT1 only translates 'he answered', without translating the projected clause 'quite so', and two modifying clauses serve as an enhancement.

Example 8 shows the omission of the projecting clause.

\section{Example 8}

ST: "I've heard that voice before," said Holmes, staring down the dimly lit street.

$\begin{array}{lllll}\text { TT1 } & \text { 福 } & \text { 乃 } & \text { 低语 } & \text { 曰, } \\ \text { PY: } & \text { fú } & \text { nǎi } & \text { dīyǔ } & \text { yuē } \\ \text { IG: } & \text { Holmes } & \text { then } & \text { whisper } & \text { say } \\ \text { BT: } & \text { Holmes } & \text { then } & \text { whispered } & \end{array}$

$\begin{array}{llllll} & \text { 华生, } & \text { 此 } & \text { 语声 } & \text { 颇 } & \text { 熟. } \\ \text { PY: } & \text { huá shēng } & \text { cř } & \text { yǔ shēng } & \text { pō } & \text { shú } \\ \text { IG: } & \text { Watson } & \text { this } & \text { voice } & \text { quite } & \text { familiar } \\ \text { BT: } & \text { Watson } & \text { this } & \text { voice } & \text { is quite familiar. }\end{array}$

$\begin{array}{lllllll}\text { TT2 } & \text { “我 } & \text { 以前 } & \text { 听见 } & \text { 过 } & \text { 那 } & \text { 声音,” } \\ \text { PY: } & \text { wǒ } & \text { yǐ qián } & \text { tīng jiàn } & \text { guò } & \text { nà } & \text { sheng yīn } \\ \text { IG: } & \text { I } & \text { past } & \text { hear } & \text { ASP:pf } & \text { that } & \text { voice } \\ \text { BT: } & \text { I } & \text { heard that voice before } & & & \end{array}$

$\begin{array}{lllllllll} & \text { 福尔摩斯 } & \text { 惊讶 } & \text { 地 } & \text { 凝视 } & \text { 着 } & \text { 昏暗 } & \text { 的 } & \text { 街道 } \\ \text { PY: } & \text { fú ěr mó sī } & \text { jīng yà } & \text { dì } & \text { níng shì zhe } & \text { hūn àn } & \text { de } & \text { jiē dào } \\ \text { IG: } & \text { Holmes } & \text { surprise } & \text { VPART } & \text { stare } & \text { ASP } & \text { dim } & \text { SUB } & \text { street } \\ \text { BT: } & \text { Holmes } & \text { stared at the dim street in surprise } & & & \end{array}$

$\begin{array}{ll} & \text { 说, } \\ \text { PY: } & \text { shuō } \\ \text { IG: } & \text { say } \\ \text { BT: } & \text { said }\end{array}$


TABLE 9 Choices made by the translators of TT1 and TT2

\begin{tabular}{lrrlrl}
\hline & TT1 & TT2 & & TT1 & TT2 \\
\hline Same as the st & 27 & 81 & & & \\
Addition & 19 & 0 & Add: projected clause & 16 & 0 \\
& & & Add: projecting clause & 3 & 0 \\
Omission & \multirow{2}{*}{34} & \multirow{2}{*}{$\begin{array}{l}\text { Omit: projected clause } \\
\text { Omit: projecting clause }\end{array}$} & 8 & 0 \\
& & & Omit: both & 17 & 0 \\
\hline
\end{tabular}

TT1 shows the partial omission of the hypotactically dependent clause that qualifies the projecting clause, and therefore the relation of hypotactic enhancement is omitted in TT1.

On the basis of the above three examples, we find that certain logicosemantic relations are missing because the projecting clause or the projected clause or both have been omitted during the translation process.

By analysing and comparing the two translations of $A$ Scandal in Bohemia, the following preliminary summary is obtained: different choices are made by the translators of т 1 and тT2, as seen in Table 9. In particular, addition and omission are identified in TT1: (1) When comments are added by the translators to the projected clause and projecting clause, the logico-semantic relation of extension is used; and when explanations of logical reasoning are added, the logico-semantic relation of enhancement is used. (2) Certain logico-semantic relations are missing because the projecting clause or the projected clause or both are omitted during the translation process.

Translators always leave traces of themselves in their translations, whether consciously or unconsciously. That is why we say that one thousand translators will produce one thousand different Hamlets. There is no translation without a translator. Within the scope of this study, we have come across different translators and the various choices they have made when translating the text. As far as this study is concerned, the translators of the earlier translation (Тт1) tend to resort to drastic changes such as omission or addition, thus rendering translations that are more acceptable to the target readers' tastes, while the translators of the later translation (тт2) prefer to maintain the structure and information of the original text. 
On the basis of the above analysis and the comparisons that were made between TT1 and TT2 of the source text A Scandal in Bohemia, the following generalisations can be made:

(1) Theme: From the preliminary analysis and findings of this study, it can be seen that it is more important to analyse Theme than Mood and Modality or Transitivity in verbal projection. Thematic differences are more noticeable than differences in mood or transitivity.

(2) TT1: The comparisons made between TT1 and TT2 suggest that the translation process produces more variation in TT1 when compared with the ST. For instance, in terms of textual Theme, TT1 chooses more textual Themes than the ST, while TT2 is more faithful to the ST.

(3) Semantic varieties: the logico-semantic analysis also highlights differences in the translation process.

(4) Translators' choices: The translators made different choices in the two different historical periods.

In summary, the projecting clauses of verbal clauses were analysed in sections 3.1 to 3.3, by considering their textual, interpersonal and experiential features, in an attempt to compare the linguistic features of the ST and its two Chinese translations. We examined 70 verbal clauses projecting direct speech and 12 verbal clauses projecting indirect speech. The three perspectives of THEME, MOOD and MODALITY, and TRANSITIVITY were explored by analysing the 70 verbal clauses projecting direct speech. In general, TT2 was found to be similar to the ST in terms of MOOD and MODALITY, and PROCESS, while TT1 and TT2 differed from the ST in terms of topical Themes because of Chinese linguistic features. Section 3.4 examined the logico-semantic relations between the ST and its two Chinese translations in verbal clause complexes, in order to investigate the various choices made by the translators of TT1 and TT2. For instance, circumstantial elements can be translated, but the translators chose to either ignore them or translated them in some other way. Although some similarities were shared between TT1 and TT2, notable differences were identified in terms of their linguistic features. In section 4, further examples were analysed and compared in the two Chinese translations, to identify the choices made by the translators. In comparison to the translators of $\mathrm{TT} 2$, the translators of TT1 were found to be more flexible, because, when compared to the source text, they incorporated more addition and omission into their translation.

This is only a preliminary study of one pilot text, but some interesting findings have been revealed from the analysis of two translations from different time periods, in particular thematic differences and various logico-semantic 
relations. If more texts were to be collected and analysed, the findings obtained might display more variations between the two translations.

\section{Yan Wang}

Yan Wang obtained her Ph.D. in linguistics from the Hong Kong Polytechnic University, Hong Kong, China in 2015, and have worked as a full-time lecturer in the Department of Translation, the Chinese University of Hong Kong since 2016. Her research interests include systemic functional linguistics, discourse analysis, descriptive translation studies, and legal translation.

\section{References}

Ary, Donald. 1979. Introduction to Research in Education, 2nd Edition. New York.

Halliday, Michael A. K., and Christian M. I. M. Matthiessen. 2004. An Introduction to Functional Grammar, 3rd edition. London: Edward Arnold.

Halliday, Michael A. K., and Christian M. I. M. Matthiessen. 2014. Halliday's Introduction to Functional Grammar, 4th edition. London and New York: Routledge.

Halliday, Michael A. K., and Edward McDonald. 2004. Metafunctional profile of the grammar of Chinese. In:Alice Caffarel,J.R. Martin, and Christian M. I. M. Matthiessen (eds.), Language typology: a functional perspective. Amsterdam: John Benjamins Publishing Company, 305-396.

Hermans, Theo. 1999. Translation in Systems: Descriptive and System-oriented Approaches Explained. Manchester: St. Jerome Publishing.

Holmes, James S. 1972. The Name and Nature of Translation Studies. Amsterdam: Translation Studies Section, University of Amsterdam, Department of General Literary Studies. Reprinted in James S. Holmes, 1988. Translated!: Papers on Literary Translations and Translation Studies. Amsterdam: Rodopi, 67-80.

Liang, Hongyan and Lei Zeng. 2016. 功能语言学视阈下的投射语言翻译研究 [Translation Studies of Projection: A Functional Perspective], 北京科技大学学报 [Journal of the University of Science and Technology Beijing] 32(117): 12-16.

Matthiessen, Christian M. I. M., and Kazuhiro Teruya. 2013. Projection in English: the environment of quoting. Indian Journal of Applied Linguistics 39(2): 50-81.

Toury, G. 1995. Descriptive translation studies and beyond. Amsterdam \& Philadelphia: John Benjamins Publishing Company.

Wierzbicka, Anna. 1987. English speech act verbs: a semantic dictionary. Cambridge, Mass.: Academic Press Inc.

Yu, Qihong. 2004. 中国现代翻译侦探小说的意义 [Significance of China's modern translation of detective stories].Journal of Guangzhou University 3(7). 
Zeng, Lei. 2006. 投射语言研究 [A Functional Interpretation of Projection]. 中山大学出 版社 [Sun Yat-sen University Press].

Zeng, Lei, and Hongyan Liang. 2019. 英汉投射语言对比研究 [A Comparative Study of Projection Between English and Chinese]. 外语教学与研究出版社 [Foreign Language Teaching \& Research Press].

Zhang, Jie. 2010. 福尔摩斯走进中国 - 多元系统视角下的晚清侦探小说翻 [Sherlock Holmes to China - translation of detective stories in late Qing period from polysystem theory]. 江苏大学硕士论文 [Master Degree Dissertation from Jiangsu University].

Zhang, Ping. 2002. 侦探文学在中国的两次译介热潮及其影响 [Two translation upsurges of detective stories in China and their influences]. Chinese Translators Journal 23(3): 53-55.

Zhang, Wenqing, and Benchun Lin. 2006. 〈福尔摩斯探案集〉的汉译状况及部分译本 评析 [The Chinese translation of The Complete Sherlock Holmes and assessment of partial translations]. 三明学院学报 [Journal of Sanming College] 1: 31-34. 